\title{
Surgery and surgeons, their historical evolution
}

\author{
Cirugía y cirujanos, su devenir histórico
}

\author{
G. Manuel Marrón-Peña* \\ Academia Mexicana de Cirugía, Colegio Mexicano de Anestesiología, Mexico City, Mexico
}

Relevant sources refer that in the scientific events organized by medical surgeons in the first third of the twentieth century, some topics related to anesthesiology were included in their academic programs. Among the important courses where doctors participated was the one organized in 1930 by the Mexican Medical Association at Hospital Juárez, and another carried out in 1932 by the Hospital General Medical Society of Mexico City ${ }^{1,2}$.

The year of 1933 is a milestone in the history of national medicine. In those days, a political project that promoted education and health for the entire population was implemented, and there were also other three important events that helped to frame the birth of the Mexican Academy of Surgery (AMC - Academia Mexicana de Cirugía) and the Mexican College of Anesthesiology (1934), formerly the Mexican Society of Anesthesiology:

- The AMC was founded on January 13, 1933, with its articles of incorporation being signed by 60 eminent surgeons, including its first chairman, Academician Dr. Gonzalo Castañeda Escobar, as well as three doctors of great vision, all three trained as surgeons, but also highly concerned about relieving the pain caused by the surgical act, i.e.,o through anesthesia, which they would devote themselves to in body and soul for most part of their lives. These restless men were Academician Dr. Benjamin Bandera Cardeña, Academician Dr. Emilio Varela and Academician Dr. Juan White Morquecho. They are the architects of Mexican anesthesiology, they are its roots and the foundations it rests upon ${ }^{1,2}$. The AMC registration protocol was drafted on February 2, and the solemn ceremony of its foundation took place on June 2, 1933, which is regarded as the official date of its incorporation.

- In 1933, the Mexican medical community was making preparations for the celebration of the centenary of the founding of the School of Medical Sciences. For that, the National Academy of Medicine and the Faculty of Medicine of the $\mathrm{Na}$ tional Autonomous University of Mexico (UNAM) collaborated together in the organization of the great event, which contemplated a tribute to Don Valentín Gómez Farías, its founder, and to the first teachers of the school, as well as a series of historical conferences about this establishment and different courses, with one surgery course imparted by Dr. Ulises Valdés, which included an anesthesiology lesson, standing out ${ }^{2}$.

- On February 1, 1933, Dr. Ignacio Chávez Sánchez took office as director of the Faculty of Medicine of the UNAM in the old Palace of Medicine, which once was the venue of the Holy Inquisition. The new officer immediately joined the organization of the centennial celebrations, as well as the AMC did; the celebrations culminated on October 23, 1933, giving rise to a more scientific Mexican surgical medicine $e^{1,2}$.

The aforementioned antecedents, among others, frame the growing concern there was among medical surgeons, particularly in those who practiced anesthesiology, who wanted to group together in order to share their experiences, communicate the research they did, and make their cultural, academic and professional motivations known. They wanted to organize courses and publish events about the disciplines they practiced.

\section{Correspondence:}

${ }^{*}$ G. Manuel Marrón-Peña

Sebastián Lerdo de Tejada, 37

Col. Del Carmen Coyoacán, Del. Coyoacán

C.P. 04100, Ciudad de México, México

Date of reception: 05-02-2018

Date of acceptance: 08-02-2018

E-mail: gmanuelmarronp@yahoo.com.mx

DOI: 10.24875/CIRUE.M18000032

Cir Cir. 2018;86:186-187

Contents available at PubMed www.cirugiaycirujanos.com 
Table 1. Some editorial directors of the Cirugía y Cirujanos ${ }^{1}$ journal

\begin{tabular}{lll}
\hline Name & Charge & Period \\
\hline Acad. Dr. José Aguilar Alvares & First director & August 1933 to December 1936 (initiation) \\
Acad. Dr. Manuel Mateos Fournier & Director manager & February 1942 to January 1944 (10"t anniversary, 1943) \\
Acad. Dr. Guillermo Alamilla Gutiérrez & Director & February 1956 to February 1958 (25 $5^{\text {th }}$ anniversary, 1958) \\
Acad. Dr. Nicolás Figueras Carrera & Director and editor & January 1982 to December 1984 (50 anniversary, 1983) \\
Acad. Dr. Alejandro Reyes Fuentes & Director & (75 anniversary, 2008) \\
Acad. Dr. Raúl Carrillo Esper & Editor & From January 2018 up to today \\
\hline
\end{tabular}

That 1933 of cultural, educational and scientific effervescence was a driving force for everyone wanting to act, to collaborate, to participate and to be creative. Plans and projects were made, some of which would fail, but others were to be the preamble of future and major events, as the creation of the Cirugía $y$ Cirujanos (Surgery and Surgeons) journal was in 1933. Only a shortly after the AMC was founded, the first issue of this journal was published in August, becoming its official journal, which retains its original name and appears bimonthly in an uninterrupted manner up to this day, and which is the purpose and main reason for this editorial article $e^{1,3}$. The work carried out by its executives has been arduous, tenacious and continuous. The vicissitudes were and are always many, primarily the economic ones. This is why I want to pay a great tribute to all those who have collaborated to its publication, without forgetting the first treasurer, Academician Dr. Francisco J. Campos L., who in some occasions donated some valuable jewel to defray the publication costs, which initially was monthly and was paid for by the AMC itself and by the Ministry of Health ${ }^{1,3}$. It is the lack of space that only allows for me to mention those directors or editors who have been present in the early years, in the tenth, twenty-fifth, fiftieth and seventy-fifth years, and to allude to the current director, because these are the most historically representative years of our publication's academic life. Table 1 mentions these managers, and therefore I offer an apology to all those who were omitted, as already said, due to the lack of space, but the complete list appears in the book Historia de la Academia, by Hurtado Andrade'.

It should be noted that among the 60 AMC and Cirugía y Cirujanos founders there are surgeons dedicated to anesthesiology and that their careers were especially consecrated to it to the point that, on November 20,1934, together with other colleagues, they followed the example and created the Society of Anesthetists of Mexico ${ }^{2,4,5}$, which as of 1948 was named Mexican Society of Anesthesiology, and since 1994 bears the name of Mexican College of Anesthesiology $y^{2,45}$. Academician Dr. Raúl Carrillo Esper was its chairman in the 2006-2007 biennium, and he also chaired the Society of Critical Medicine and Intensive Therapy. He is a member of the National Academy of Medicine and full member of the AMC, which he joined in 2000, demonstrating his great bonhomie and interest in research and teaching, which made him worthy to be appointed head of the Teaching Commission of our corporation. Since 2008, he is the editorial director of Revista Mexicana de Anestesiología and of Clínicas Mexicanas of this specialty, as well as the author of several texts on the subject, which ensures great experience in medical publications, thus guaranteeing that Cirugía y Cirujanos will be safe, in very good hands since this 2018, and that it will continue with its superb trajectory, certainly increasing its great relevance within Mexican surgery day by day, because Dr. Carrillo Esper, as its new editor, will achieve the established objectives and those to be proposed by the partners and executives. Congratulations to our journal and our institution. May success crown his administration for the sake of academicians and Mexican surgery and medicine.

\section{References}

1. Hurtado AH. Revista Cirugía y Cirujanos. En Hurtado AH, editor. Historia de la Academia Mexicana de Cirugía. 1933-2002. México: Copias Gráficas S.A de C.V.; 2005. p. 231-50.

2. Marrón PM. Antecedentes históricos del Colegio Mexicano de Anestesiología, antes Sociedad Mexicana de Anestesiología. Sus orígenes, evolución y trascendencia. 1934-1995. Rev Mex Anest. 2013; 36:136-54.

3. Hurtado AH, Sigler MI, De la Torre Bravo A. Breve reseña histórica de Cirugía y Cirujanos. Cir Ciruj.1998;66:207-11.

4. Bandera B. Historia de la anestesiología en México: evolución y desarrollo futuro. Rev Mex Anest. 1960;(9):83-94.

5. Aldrete JA. Historia de la anestesiología. Texto de anestesiología teórico-práctica. México: Salvat Mexicana de Ediciones; 1986. p. 3-23. 